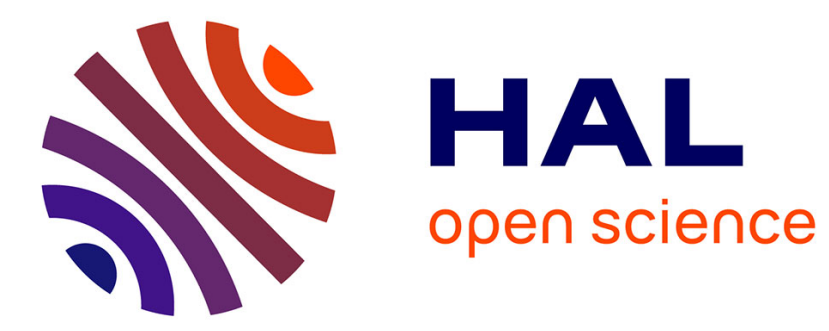

\title{
Biomarker induction in tropical fish species on the Northwest Shelf of Australia by produced formation water
}

Shiqian Zhu, Susan Codi King, Mary L. Haasch

\section{- To cite this version:}

Shiqian Zhu, Susan Codi King, Mary L. Haasch. Biomarker induction in tropical fish species on the Northwest Shelf of Australia by produced formation water. Marine Environmental Research, 2008, 65 (4), pp.315. 10.1016/j.marenvres.2007.11.007 . hal-00562997

\section{HAL Id: hal-00562997 https://hal.science/hal-00562997}

Submitted on 4 Feb 2011

HAL is a multi-disciplinary open access archive for the deposit and dissemination of scientific research documents, whether they are published or not. The documents may come from teaching and research institutions in France or abroad, or from public or private research centers.
L'archive ouverte pluridisciplinaire HAL, est destinée au dépôt et à la diffusion de documents scientifiques de niveau recherche, publiés ou non, émanant des établissements d'enseignement et de recherche français ou étrangers, des laboratoires publics ou privés. 


\section{Accepted Manuscript}

Biomarker induction in tropical fish species on the Northwest Shelf of Australia by produced formation water

Shiqian Zhu, Susan Codi King, Mary L. Haasch

PII:

S0141-1136(07)00149-3

DOI:

10.1016/j.marenvres.2007.11.007

Reference:

MERE 3159

To appear in:

Marine Environmental Research

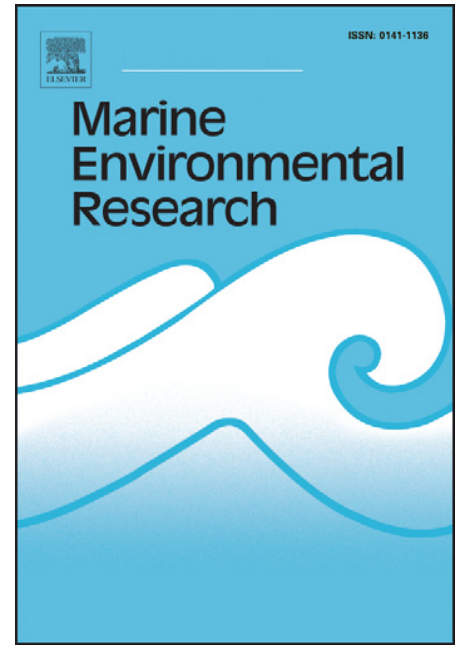

Received Date: $\quad 5$ May 2006

Revised Date: $\quad 24$ June 2007

Accepted Date: $\quad 20$ November 2007

Please cite this article as: Zhu, S., King, S.C., Haasch, M.L., Biomarker induction in tropical fish species on the Northwest Shelf of Australia by produced formation water, Marine Environmental Research (2007), doi: 10.1016/ j.marenvres.2007.11.007

This is a PDF file of an unedited manuscript that has been accepted for publication. As a service to our customers we are providing this early version of the manuscript. The manuscript will undergo copyediting, typesetting, and review of the resulting proof before it is published in its final form. Please note that during the production process errors may be discovered which could affect the content, and all legal disclaimers that apply to the journal pertain. 


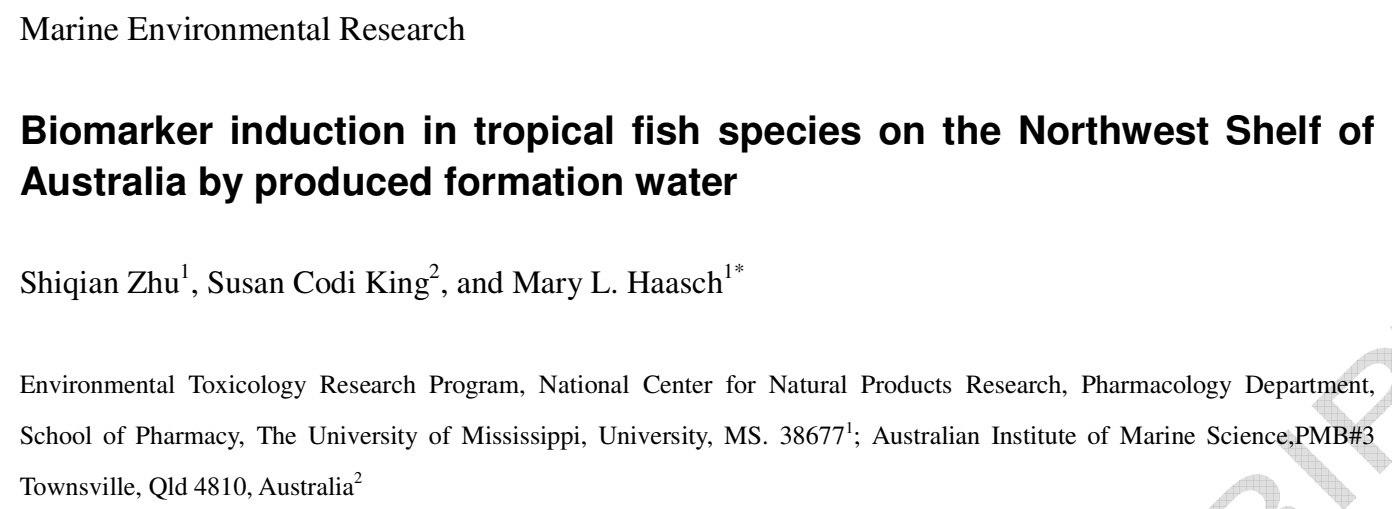

Contact Information

16

17

The University of Mississippi

School of Pharmacy, NCNPR, ETRP

347 Faser

University, MS 38677-1848

T: 662-915-5958

F: 662-915-1285

E: mlhaasch@olemiss.edu

*Current Address

USEPA, MED

NRC Research Associate, Senior Scientist

6201 Congdon Blvd.

Duluth, MN 55804

T: 218-529-5172

F: 218-529-5003

E: Haasch.Mary@epa.gov 


\section{ABSTRACT}

Normal operation of oil well platforms results in the discharge of produced formation water (PFW). The expression of CYP1A, CYP2M1- and 2K1-like proteins was examined for use as possible biomarkers of PFW exposure. A pilot study on the Northwest Shelf of Australia had indicated that PFW contamination possibly contributes to induction of CYP1A-like proteins in Gold-Spotted Trevally (Carangoides fulvoguttatus). The pilot study samples were re-examined for CYP1A, and, in addition, CYP2K1/2M1-like proteins. In a subsequent caged-fish study in the same location a second species, Stripey seaperch (Lutjanus carponotatus), caught at a clean site, were distributed to three caging sites in a PFW gradient from the Harriet A production platform: A (near-field), B (far-field) and C (a non-impacted reference site). Fish were sampled at time (T) $\mathrm{T}=0, \mathrm{~T}=3$ and $\mathrm{T}=10$ days. Significant increases of CYP1A, one CYP2K1- and two CYP2M1-like proteins were noted at Site A at T=10 d. For another CYP2K1-like protein, a significant increase was observed at Site A only at $\mathrm{T}=3 \mathrm{~d}$. These results support a previous study indicating that CYP1A protein is sensitive to PFW exposure. Importantly, statistically significant environmental induction of both CYP2M1- and CYP2K1-like proteins in tropical fish due to PFW exposure had not previously been described and induction of enzymes in the CYP2 family suggest new biomarkers for PFW. In addition, the novel response of one CYP2K-like protein requires further verification, but offers promise for improved monitoring of sub-lethal responses in marine organisms.

Keywords: CYP1A, CYP2K1, CYP2M1, produced formation water, tropical fish, Australia, biomarkers

\section{Introduction}

Produced formation water (PFW), the oily water usually discharged from a platform after separation from the oil, is made up from formation water (water associated with the oil in the reservoir) and potentially includes water which was injected into the reservoir to maintain pressure for oil production (Holdway, 2002). As oil fields age, the amount of PFW increases as the reservoir fills with injected water (Henderson et al., 1999).

When discharged, the PFW contains a large variety of naturally occurring materials from the formation, which include residual volatile and non-volatile hydrocarbons not removed by the separation regime, and also contains chemicals added to the production stream (Burns et al., 1999). Therefore, the composition of the discharged PFW is very complex. Almost all offshore oilfields produce formation water that can have significant environmental effects if not handled properly. Australia's oil and gas production activity is predominantly on the Northwest Shelf of Western Australia, off 
the continental margins between the North West Cape and Dampier (Swan et al., 1994). There has been excellent work on the toxicology of PFW (Holdway, 2002; Neff, 2002; Neff et al., 2006). Unfortunately, little is known of the effects of PFW on the tropical marine environment, especially for tropical reef fish. One study demonstrated minor toxicity of PFW from Harriet A oil platform to corals and their symbiotic algae (Jones and Heyward, 2003). Another study illustrated a preliminary toxicological assessment of PFW including analytical detection and acute toxicity bioassay using European sea bass larvae (Mariani et al., 2004). An independent scientific review commissioned by the Australian Petroleum Production and Exploration Association (APPEA) and the Energy Resource Development Corporation (ERDC) highlighted the need to conduct environmental assessments of industry practices in shallow coastal ecosystems around Australia.

In 1998, the Australian Institute of Marine Science (AIMS) conducted a pilot study to evaluate the use of sub-lethal stress indicators in fish for assessing exposure to organic contaminants associated with PFW discharged from an oil and gas production platform on the Northwest Shelf of Australia. The pilot study results confirmed that within $1000 \mathrm{~m}$ from the Harriet A platform there was potential for biological effects in fish populations exposed to PFW effluent and that further investigation was warranted at this site (Codi King et al., 2005a). For this study, these samples were re-examined for CYP1A using more universally repeatable conditions, and, in addition, the response of CYP2K1/2M1-like proteins was determined. In May 2003, AIMS conducted a comprehensive biological and chemical assessment of PFW effluent at the Harriet A platform. This more comprehensive study utilized a controlled system in which fish from a reference site were collected and placed in cages, and the cages were located in a gradient line moving away from the point source of PFW being discharged at Harriet A. The work described here is a subset of the suite of biomarkers conducted for the 2003 study and presents in detail the cytochrome protein biomarkers in an ecologically relevant reef species, Stripey seapearch (Lutjanus carponotatus) for the evaluation of the potential effects of PFW discharge at the Harriet A Platform on the Northwest Shelf of Australia.

\section{Materials and Methods}

\subsection{Pilot study: study site and fish collection}

Harriet A, an oil and gas production platform located $135 \mathrm{~km}$ west of Karratha on the Northwest Shelf of Australia, was the main focus of this study (Figure 1). The hydrocarbon concentration of PFW effluent in the sea-surface micro-layer, water column, sediments and biota, at this location, have been well documented (Burns and Codi, 1999) The site selections for the pilot study have previously been described in Codi King et al. (2005a). Gold-spotted Trevally was chosen for the pilot study because of its importance both commercially and recreationally to the NW Shelf of Australia. A total of 41 Gold-spotted Trevally were collected from each of three sites: Harriet A $(n=23$, Mean \pm SD; $3817 \pm 1532$ g total weight, $654 \pm 103 \mathrm{~mm}$ total length, age 1-5 yr); Harriet $C(n=6$, Mean $\pm S D ; 3608 \pm 1503$ g total weight, $654 \pm 103 \mathrm{~mm}$ 
125

126

127

128

129

130

131

total length, age 2-6 yr); and reference site off the Montebello Islands ( $\mathrm{n}=12$, Mean \pm $\mathrm{SD} ; 3992 \pm 1122 \mathrm{~g}$ total weight, $660 \pm 75 \mathrm{~mm}$ total length, age $2-5 \mathrm{yr}$ ). The data demonstrated there were no significant differences in total weight, total length and age of fish between the three study sites $(P<0.05)$. All fish were processed as previously described in Codi King et al. (2005a). Briefly, livers were removed, frozen in liquid nitrogen and transported to AIMS via a liquid nitrogen dry shipper remaining stored in liquid nitrogen until thawed for microsomal preparation (see Section 2.3). 


\subsection{Caged fish study: Study site and fish collection}

The PFW plume from Harriet A forms a fine surface slick that moves in a NNW direction on the ebb tides and SSE direction on the flood tide. The PFW hydrocarbons in the sea-surface microlayer were detectable to a distance of $1 \mathrm{~km}$. The lighter MW components (naphthalene and homologs) were in the dissolved phase while the heavier MW hydrocarbons (phenanthrene and homologs) were associated with the particulate phase. The particulate phase was removed from the water column within a distance of $0.9-2 \mathrm{~km}$ of Harriet A (Burns and Codi, 1999; Holdway and Heggie, 1998). Therefore for the caged fish study, the cages were situated along the gradient of PFW formed as the plume moves away from the discharge site. Site A (within 200 m NNW of Harriet A) was the near-field site; Site B ( $1000 \mathrm{~m} \mathrm{NNW}$ of Harriet A) was the far-field site and Site C $(\sim 20 \mathrm{~km} \mathrm{NNW}$ of Harriet A; in the Montebello Islands) was chosen as the reference site due to the lack of known contamination (Figure 2). The field component of this project was conducted aboard the AIMS $R V$ Cape Ferguson from May 16-31, 2003. Initially, the target species was Red Emperor (Lutjanus sebae), since it could be caged successfully (Mike Cappo, pers. comm.). On the first day of collection; however, only 5 juvenile $L$. sebae were caught and another species, Stripey seaperch (Lutjanus carponotatus) were being trapped at a much higher proportion (10:1). L. carponotatus is an important recreational fishery in Dampier Harbor and preliminary biomarker research with this species from the Harriet A pilot study (Codi et al., 2001) suggested that it would suffice as a substitute species for L. sebae. From May 16-19 2003, an estimated 130 L. carponotatus were collected by fish traps along the Dampier Harbor LNG pipeline and maintained in a 1000-L holding tank with running seawater and air. On May 21, all fish were placed in cages with 2 cages per station, 15 fish per cage at each of 3 sites (Figure 2). Fish were fed individually quick frozen (IQF) pilchards of the highest quality (Western Australia Bait Supply, Fremantle), collected from clean local waters off of Albany, WA. Food canisters were replenished every two days during the field exposure. Fish were sampled at $\mathrm{T}=0,3$ and $10 \mathrm{~d}$.

A total of 50 Stripey seaperch were analyzed for CYP1A, CYP2M- and CYP2K-like proteins from the holding tank $(\mathrm{T}=0)$, and $\mathrm{T}=3$ and $\mathrm{T}=10$ for cage Sites $\mathrm{A}, \mathrm{B}$, and $\mathrm{C}$. There were no significant differences for total weight, total length and age between the study sites $(P<0.05$; Table 1$)$. All fish were handled and processed in a similar manner as stated for the pilot study.

\subsection{Microsomal preparation and Western blot}

Hepatic microsomal samples were prepared at the Australian Institute of Marine Science, Townsville, Qld (AIMS) following methods previously described (Haasch, 2002) and shipped on dry ice to The University of Mississippi, University, MS. Hepatic microsomal samples were stored at $-80^{\circ} \mathrm{C}$ until analyzed. Protein content of the microsomal fraction was determined by Bio-Rad DC Protein Assay (Hercules, CA) using bovine serum albumin (BSA) as a standard. Microsomal proteins (10 $\mu \mathrm{g}$ 
per well) were separated using pre-cast Criterion SDS-PAGE gels $(10 \% \mathrm{~T}, 2.7 \% \mathrm{C}$ resolving gel; 4\% T, 2.7\% $\mathrm{C}$ stacking gel; Bio-Rad) at 200V for $1 \mathrm{~h}$ with the Bio-Rad Criterion apparatus. Proteins were then electrotransferred ( $100 \mathrm{~V}$ for $0.75 \mathrm{~h})$ to a PVDF membrane (FluoroTrans W, $0.2 \mu \mathrm{m}$; VWR) together with one lane containing MagicMark protein standards (contain proteins with IgG binding site; Invitrogen, Carlsbad, CA) detectable by chemiluminescence, for molecular weight determination and for evaluation of transfer efficiency. Sample loading buffer also contained Pyronin $\mathrm{Y}$ which is visible on the membrane and marks the dye front. Detection of proteins of interest was accomplished by using one of the primary polyclonal antibodies; rabbit anti-fish CYP1A (two synthetic peptides used as immunogens; BioSense, Bergen, NO distributed by Cayman Chemical, Ann Arbor, MI), rabbit anti-trout CYP2K1, rabbit anti-trout CYP2M1 (both gifts from Donald R. Buhler, $\mathrm{PhD}$, Oregon State University, Corvallis, OR). Proteins of interest were visualized with goat anti-rabbit alkaline phosphatase conjugate (Bio-Rad) and the Western Breeze Novex Western Blot Immunodetection Kit (Invitrogen) according to the manufacturer's directions using Western Lightening CDP-Star Chemiluminescent reagent (Perkin Elmer Life Sciences, Boston, MA). Image analysis was accomplished using the VersaDoc 3000 Imaging System and QuantityOne analysis software (Bio-Rad). A summary of CYP1A results of the pilot study samples was previously presented (Codi King et al., 2005a) in which the samples were analyzed with a different primary antibody (anti-trout CYP1A1 $277-294 / \mathrm{KLH}$ ) under different SDS-PAGE conditions (mini-Protean II, individually poured gels in the previous study) and with different methods for quantification (film, scanning densitometry and NIH Image ${ }^{\circledR}$ in the previous study). For this study, a commercially available antibody was used and the number of samples that could be compared on one gel was increased improving the statistical analyses.

\subsection{Densitometry and Statistical Analysis}

The optical density of the samples is given as a Trace Quantity (QTY; Bio-Rad QuantityOne) or the quantity of a band as measured by the area under its intensity profile curve. Trace QTY units are intensity ×area. For standardization, one sample in triplicate was loaded on each gel. The mean Trace QTY of this sample was used as a gel factor for standardization between gels. Trace QTY results are presented as an Arbitrary Optical Density (without gray-scale calibration). Statistical analysis was performed using GraphPad Prism. For the pilot study, a two-way ANOVA was performed using both gender and site as covariates. The results indicated that for each individual isozyme site was a significant factor, but not gender, and there were no interactions between these two factors. Therefore, for the one-way ANOVA the males and females were pooled, and the ANOVA results were analyzed by Turkey's multiple comparison test $(P<0.05,0.01$ and 0.001$)$. Similar analysis of covariates allowed the use of the same statistical approach for the caged fish study.

\section{Results}

\subsection{Pilot study}


The results of the immunodetection of the CYP1A-, CYP2M1-, and CYP2K1-like proteins indicated that proteins of the appropriate molecular weight range for each isozyme were detectable in Gold-Spotted Trevally. Most Gold-Spotted Trevally showed one immunodetectable band of CYP1A-, CYP2M1- and CYP2K1- like proteins; some samples had a second CYP2M1- like protein. Because this second protein was not present in each sample, only the first band of lower molecular weight was quantified (Figure 3). Similar to the previous study (Codi King et al., 2005a), CYP1A-like protein levels in Gold-Spotted Trevally from the near-field (Harriet A) site were significantly higher than those from the far-field (Harriet $\mathrm{C}$ ) site and the reference site. Although not significant, Gold-Spotted Trevally also exhibited a trend of increased CYP2M1-like protein levels at Harriet A as compared to Harriet C and the reference site (Figure 3).

For CYP2K1-like protein, a significant increase was observed at the Harriet C site compared to the reference site (Figure 3). The induction of CYP2K1-like proteins at the Harriet $\mathrm{C}$ site in Trevally may be due to possible exposure to hydrocarbons from natural oil seepages found in this region, or due to the movement of fish between platforms. The elimination of these variables was one of the main reasons for undertaking the subsequent controlled field study using caged fish.

\subsection{Caged fish study}

Immunodetection of CYP1A-like proteins indicated that proteins of the appropriate molecular weight range were detectable in Stripey seaperch at all three sites and over the time of the exposure (Figure 4a). The results for the CYP1A-like proteins (Figure 4b) demonstrated that by Day 3 of exposure both Site A and Site B had higher mean values than Site C, albeit not significant. By Day 10, fish collected at Site A had significantly higher induction of CYP1A-like proteins as compared to the fish at Site B and Site C. Comparisons also demonstrated that Site A fish after 10 days of exposure had significantly induced levels of CYP1A-like proteins as compared to the holding tank fish $(\mathrm{T}=0)$.

Figure 5a presents the optical densities for the species-specific pattern of CYP2M1-like proteins determined in Stripey seaperch, with two distinct appropriate molecular weight proteins in most samples; CYP2M1-like Protein $1(52.8 \mathrm{kDa})$ and CYP2M1-like Protein $2(49.0 \mathrm{kDa})$. Immunodetection of CYP2M1-like proteins demonstrated a similar pattern of expression for both Protein 1 and Protein 2 in Stripey seaperch with significant induction occurring at Day 10 for both proteins (Figures 5b and 5c) and at Day 3 the same increasing but not significant trend. For Site A both Day 3 and Day 10 exposed Stripey seaperch had significantly higher levels of CYP2M1-like proteins than the holding tank fish. It is interesting that Site C Day 3 exposed fish also demonstrated site-specific differences from the holding tank fish.

Figure 6a presents the optical densities for the species-specific pattern of CYP2K1-like proteins determined in Stripey seaperch, again showing two distinct appropriate molecular weight proteins; CYP2K1-like Protein $1(52.5 \mathrm{kDa})$ and 
CYP2K1-like Protein $2(48.2 \mathrm{kDa})$. Unlike the two CYP2M1-like proteins, the induction patterns for the two CYP2K1-like proteins were dissimilar. For CYP2K1-like Protein 1, levels (Figure 4b) were significantly elevated for Site A Day 3 as compared to fish collected on Day 3 from Site B and Site C. At Day 10 there were no site-specific differences in expression, although Site A Day 10 and Site A Day 3 Stripey seaperch had significantly higher CYP2K1-like Protein 1 levels than the holding tank fish. For CYP2K1-like Protein 2 levels (Figure 4c) the induction trend was similar to the pattern observed for CYP1A- and both CYP2M1-like Protein 1 and Protein 2 in that by Day 10, Site A fish demonstrated the highest mean level of induction. The same site-specific differences were also observed with Site A Day 10 fish and Day 3 fish having significantly higher CYP2K1-like Protein 2 induction levels than the holding tank fish.

\section{Discussion}

Fish are important organisms for monitoring environmental contaminants because of their position in the food web, their lifestyle, their relative abundance and their adaptable physiology. Fish CYP1A induction is an extremely useful biomarker of chemical exposure in the environment (Flammarion et al., 2002), particularly for persistent pesticides (Levine et al., 1999), polychlorinated biphenyls (Burton et al., 2002; Haasch et al., 1993), dioxins (Zodrow et al., 2004; Smith, 2003), pulp mill effluents (Oikari et al., 2002), xenoestrogens (Katchamart et al., 2002), spilled crude oil (Jewett et al., 2002), and polycyclic aromatic hydrocarbons (PAHs) (Stagg et al., 2000). The induction of CYP1A has implications for human fish consumption, as well as for the health status of aquatic organisms (Arinc et al., 2000).

The induction of CYP2 family proteins in bluegill and catfish due to exposure to peroxisome proliferating agents (PPAs; Haasch, 1996) was the first description of an inducible P450 in fish other than CYP1A. The CYP2M1- and 2K1-like proteins in bluegill and catfish were later shown to be lauric acid hydroxylases (Haasch et al., 1998). Bivalves exposed to petroleum water-accommodated fraction (WAFs) produce peroxisome proliferation (Cajaraville et al., 1997). Therefore, petroleum hydrocarbon, as the major contaminant in PFW, may be considered a PPA, even though the mechanism is unknown. These findings provided an indication that a petroleum hydrocarbon-initiated peroxisome proliferation response may occur in lower vertebrates similar to the model PPA-mediated induction of CYP2M1/2K1 (Ackers et al., 2000; Johnson et al., 1996).

These two CYP2 family P450 isozymes have been most thoroughly characterized in rainbow trout, (Oncorhynchus_mykiss; Buhler and Wang-Buhler, 1998). The molecular weight of CYP2K1 in rainbow trout is about $54 \mathrm{kDa}$, and has been shown to catalyze the ( $\omega-1)$ and $(\omega-2)$ hydroxylation of lauric acid and some longer chain fatty acids; the molecular weight of CYP2M1 in rainbow trout is about $50 \mathrm{kDa}$, and this isozyme is the only known P450 responsible for laurate hydroxylation at the $(\omega-6)$ position. Both isozymes also catalyze the hydroxylation of estradiol, testosterone and progesterone (Buhler and Wang-Buhler, 1998). It follows that induction of CYP2K1- and 
CYP2M1-like proteins in fish may have effects on fatty acid and steroid homeostasis, with possible links to developmental and reproductive toxicity as well as carcinogenesis (Biegel et al., 1995; Vanden Heuvel, 1996; Vanden Heuvel et al., 1991). A variety of structurally diverse xenobiotics and pharmaceuticals are known to produce peroxisome proliferation and concordant fatty acid metabolizing enzyme induction in mammals, therefore, the monitoring of CYP2 family isozymes in fish may have implications for human health and has the potential to become an important indicator of environmental health.

The immunodetection results indicated one highly immunoreactive protein for CYP1A and multiple immunoreactive proteins for the CYP2-like proteins. Some cross-reactivity between CYP2-like proteins is expected with the polyclonal anti-CYP2K1 and anti-CYP2M1 antibodies (some affinity for the same protein epitopes) as these antibodies have cross-reactivity to both rainbow trout CYP2K1 and CYP2M1 (Buhler and Wang-Buhler, 1998). Further evidence for cross-reactivity was evident in samples that also included one or more minor proteins of intermediate size that were specific to individuals and not consistently represented across all individuals. The CYP2 family is known to be fairly complex in number of isozymes and expression levels (Buhler and Wang-Buhler, 1998). Multiple cross-reactivity was not unexpected and did not detract from the relatively clear induction of two proteins using the anti-CYP2 antibodies. The proteins were designated CYP2M1- and CYP2K1-like proteins because appropriate standards for the tropical fish species do not yet exist and were beyond the scope of this study. Nevertheless, it is evident that the CYP2 family antibodies recognize constitutively present and inducible proteins that could potentially be used as biomarkers. Furthermore, it is possible, with appropriate sequence information, for commercially-available anti-CYP2 family antibodies to be developed.

The pilot study CYP1A results supported the findings of an earlier analysis of those samples using a different methodology indicating induction of CYP1A (Codi King et al., 2005a). Unlike the previous analysis, the current study did not indicate gender-specific responses. Multiple differences between the two analyses could contribute to the discrepancy including the use of a different primary antibody preparation. Similar to the previous analysis, site-specific responses were detected. Analysis of the pilot study samples for CYP2M1- and CYP2K1-like proteins indicated possible site-specific induction and prompted the further examination of these proteins in the caged fish study.

Studies of environmental contaminant-mediated induction of the cytochromes P450 in tropical fish are lacking (Codi King et al., 2005a; Vrolijk et al., 1994). Both the pilot and caged fish field studies indicated significant results pertaining to the induction of cytochromes P450 in tropical fish species by PFW. First, the induction of CYP1A in Gold-Spotted Trevally and Stripey seaperch at the near-field site indicated that even though PFW discharge limits are being met (Codi King et al., 2005b), exposure to CYP1A inducing chemicals within the diluted PFW produced a significant induction 
effect. Numerous studies have demonstrated that chronic low level exposure of fish and especially larvae to PAHs can have a significant impact and can produce long-term, adverse health and reproductive effects (Incardona et al., 2004; Stegeman et al., 2001). These adverse effects are most likely to be more serious to those organisms attached to the platform or living under or near the platform in a restricted range but could also be detrimental to organisms cyclically exposed to pools of PFW. Second, the significant induction of the CYP2K1/2M1-like proteins in both the Gold-Spotted Trevally and the Stripey seaperch is the first documented significant environmental induction in fish of any cytochrome P450 isozyme other than CYP1A1. The similar induction pattern of CYP1A1 and CYP2K1-like Protein 2 and CYP2M1-like Protein 1 and 2 may indicate that all of these isozymes are induced by the same chemical class contained within the PFW. While this finding alone is a reason for further study, it is perhaps even more interesting that there is an apparent response difference for induction of particular CYP2K1/2M1-like proteins. Only the CYP2K1-like Protein 1 was induced at the near-field site (Site A) on Day 3, but not on Day 10. The apparently different induction of the CYP2K1 Protein 1 compared to the other CYP isozymes potentially represents a unique chance to develop another bioindicator of PFW exposure. Although the metabolic activities of the CYP2M1 and CYP2K1 isozymes in Stripey seaperch are not known, it is reasonable to assume that the fatty acid and reproductive steroid hormone substrates would differ among the different proteins. Induction of different isozymes may therefore have different shortand long-term effects on the exposed organisms.

In support of the previous findings, the results indicate that CYP1A protein is sensitive to PFW exposure. Importantly, statistically significant environmental induction of both CYP2M1- and CYP2K1-like proteins in tropical fish due to PFW exposure had not previously been described and CYP2 family induction may represent possible new biomarkers (other than CYP1A) associated with PFW. In addition, the novel response of one CYP2K-like protein requires further verification but offers promise for improved monitoring of sub-lethal responses in marine organisms. 
Ackers, J.T., Johnston, M.F., and Haasch, M.L. (2000). Immunodetection of hepatic peroxisomal PMP70 as an indicator of peroxisomal proliferation in the mummichog, Fundulus heteroclitus. Marine Environmental Research, 50, 361-365.

Arinc, E., Sen, A., and Bozcaarmutlu, A. (2000). Cytochrome P4501A and associated mixed-function oxidase induction in fish as a biomarker for toxic carcinogenic pollutants in the aquatic environment. Pure and Applied Chemistry, 72, 985-994.

Biegel, L.B., Liu, R.C., Hurtt, M.E., and Cook, J.C. (1995). Effects of ammonium perfluorooctanoate on Leydig cell function: in vitro, in vivo, and ex vivo studies. Toxicology Applied Pharmacology, 134, 18-25.

Buhler, D.R., and Wang-Buhler, J.L. (1998). Rainbow trout cytochrome P450s: purification, molecular aspects, metabolic activity, induction and role in environmental monitoring. Comparative Biochemistry and Physiology. Part C, Pharmacology, Toxicology and Endocrinology, 121, 107-137.

Burns, K.A., and Codi, S. (1999). Non-volatile Hydrocarbon Chemistry Studies Around a Production Platform on Australia's Northwest Shelf. Estuarine, Coastal and Shelf Science, 49, 853-876.

Burns, K.A., Codi, S., Furnas, M., Heggie, D., Holdway, D., King, B., and McAllister, F. (1999). Dispersion and fate of produced formation water constituents in an Australian Northwest Shelf shallow water ecosystem. Marine Pollution Bulletin, 38, 593-603.

Burton, J.E., Dorociak, I.R., Schwedler, T.E., and Rice, C.D. (2002). Circulating lysozyme and hepatic CYP1A activities during a chronic dietary exposure to tributyltin (TBT) and 3,3',4,4',5-pentachlorobiphenyl (PCB 126) mixtures in channel catfish, Ictalurus punctatus. Journal of Toxicology and Environmental Health, Part A, 65, 589-602.

Cajaraville, M.P., Orbea, A., Marigomez, I., and Cancio, I. (1997). Peroxisome proliferation in the digestive epithelium of mussels exposed to the water accommodated fraction of three oils. Comparative Biochemistry and Physiology, C: Pharmacology, Toxicology and Endocrinology, 117C, 233-242.

Codi King, S., Johnson, J.E., Haasch, M.L., Ryan, D.A.J., Ahokas, J.T., and Burns, K.A. (2005a). Summary results from a pilot study conducted around an oil production platform on the Northwest Shelf of Australia. Marine Pollution Bulletin 50, 1163-1172.

Codi King, S., Bennett, C., Haasch, M.L., Zhu, S., Mondon, J., Mueller, .J, McLean, C., Humphrey, C., and Shaw, M. (2005b). Chemical and biological assessment of produced formation water (PFW) effluent from Harriet A Platform, on a tropical reef species, Stripey searperch (Lutjanus carponotatus). Final Report for Apache Energy Pty. Australian Institute of Marine Science. 125 pgs.

Codi, S., Burns, K.A., Johnson, J.E., Ramsay, M., Ryan, D.J.A., and Haasch, M.L. (2001). A pilot study conducted around Harriet A petroleum production on the Northwest Shelf of Australia: Assessment of sub-lethal stress indicators in fish as potential indicators of petroleum hydrocarbon exposure. Final report to Apache Energy Pty Ltd., 73 pgs.

Flammarion, P., Devaux, A., Nehls, S., Migeon, B., Noury, P., and Garric, J. (2002). Multibiomarker Responses in Fish from the Moselle River (France). Ecotoxicology and Environmental Safety, 51, 145-153. 
Haasch, M.L. (1996). Induction of anti-trout lauric acid hydroxylase immunoreactive proteins by peroxisome proliferators in bluegill and catfish. Marine Environmental Research, 42, 287-291.

Haasch, M.L. (2002). Effects of vehicle, diet and gender on the expression of PMP70- and CYP2K1/2M1-like proteins in the mummichog. Marine Environmental Research, 54, 297-301.

Haasch, M.L., Henderson, M.C., and Buhler, D.R. (1998). Induction of lauric acid hydroxylase activity in catfish and bluegill by peroxisome proliferating agents. Comparative Biochemistry and Physiology, Part C: Pharmacology, Toxicology and Endocrinology, 121C, 297-303.

Haasch, M.L., Prince, R., Wejksnora, P.J., Cooper, K.R., and Lech, J.J. (1993). Caged and wild fish: Induction of hepatic cytochrome P-450 (CYP1A1) as an environmental biomonitor. Environmental Toxicology Chemistry, 12, 885-895.

Henderson, S.B., Grigson, S.J.W., Johnson, P., and Roddie, B.D. (1999). Potential impact of production chemicals on the toxicity of produced water discharges from North Sea oil platforms. Marine Pollution Bulletin, 38, 1141-1151.

Holdway, D., and Heggie, D.T. (1998). Tracking produced formation water discharge from a petroleum production platform to the North West shelf. APPEA Journal, 38, 665-680.

Holdway, D.A. (2002). The acute and chronic effects of wastes associated with offshore oil and gas production on temperate and tropical marine ecological processes. Marine Pollution Bulletin, 44, 185-203.

Incardona, J.P., Collier, T.K., and Scholz, N.L. (2004). Defects in cardiac function precede morphological abnormalities in fish embryos exposed to polycyclic aromatic hydrocarbons. Toxicology Applied Pharmacology, 196, 191-205.

Jewett, S.C., Dean, T.A., Woodin, B.R., Hoberg, M.K., and Stegeman, J.J. (2002). Exposure to hydrocarbons 10 years after the Exxon Valdez oil spill: evidence from cytochrome P4501A expression and biliary FACs in nearshore demersal fishes. Marine Environmental Research, 54, 21-48.

Johnson, E.F., Palmer, C.N., Griffin, K.J., and Hsu, M.H. (1996). Role of the peroxisome proliferator-activated receptor in cytochrome P450 4A gene regulation. FASEB Journal, $10,1241-1248$.

Jones, R.J., and Heyward, A.J. (2003). The effects of produced formation water (PFW) on coral and isolated symbiotic dinoflagellates of coral. Marine and Freshwater Research, 54, 153-162.

Katchamart, S., Miranda, C.L., Henderson, M.C., Pereira, C.B. and Buhler, D.R. (2002). Effect of xenoestrogen exposure on the expression of cytochrome P 450 isoforms in rainbow trout liver. Environmental Toxicology and Chemistry, 21, 2445-2451.

Levine, S.L., Oris, J.T. and Denison, M.S. (1999). Modulation of CYP1A expression in rainbow trout by a technical grade formulation of propiconazole. Environmental Toxicology and Chemistry, 18, 2565-2573.

Mariani, L., Manfra, L., Maggi, C., Savorelli, F., Di Mento, R., and Cicero, A.M. (2004). Produced formation waters: a preliminary study on chemical characterization and acute toxicity by using fish larvae (Dicentrarchus labrax L., 1758). Fresenius Environmental Bulletin 13, 1427-1432. 
Neff, J.M. (2002). Bioaccumulation in Marine Organisms: Effect of Contaminants from Oil Well Produced Water, Elsevier Science. 452 pgs.

Neff, J.M., Johnsen, S., Frost, T.K., Utvik, T.I., and Durell, G.S. (2006). Oil well produced water discharges to the North Sea. Part II: comparison of deployed mussels (Mytilus edulis) and the DREAM model to predict ecological risk. Marine Environmental Research 62, 224-246.

Oikari, A., Fragoso, N., Leppanen, H., Chan, T., and Hodson, P.V. (2002). Bioavailability to juvenile rainbow trout (Oncorhynchus mykiss) of retene and other mixed-function oxygenase-active compounds from sediments. Environmental Toxicology and Chemistry, 21, 121-128.

Smith, P.N. (2003). Environmental polychlorinated biphenyl exposure and cytochromes P450 in raccoons (Procyon lotor). Environmental Toxicology and Chemistry, 22, 417-423.

Stagg, R.M., Rusin, J., McPhail, M.E., McIntosh, A.D., Moffat, C.F., and Craft, J.A. (2000). Effects of polycyclic aromatic hydrocarbons on expression of CYP1A in salmon (Salmo salar) following experimental exposure and after the Braer oil spill. Environmental Toxicology and Chemistry, 19, 2797-2805.

Stegeman, J.J., Schlezinger, J.J., Craddock, J.E., and Tillitt, D.E. (2001). Cytochrome P450 $1 \mathrm{~A}$ expression in midwater fishes: potential effects of chemical contaminants in remote oceanic zones. Environmental Science and Technology, 35, 54-62.

Swan, J.M., Neff, J.M. and Young, P.C. (1994). Environmental Implications of Offshore Oil \& Gas Development in Australia: The findings of an independent scientific review., Australian Petroleum Production \& Exploration Association, Sydney. 125 pgs.

Vanden Heuvel, J.P. (1996). Perfluorodecanoic acid as a useful pharmacologic tool for the study of peroxisome proliferation. General Pharmacology, 27, 1123-1129.

Vanden Heuvel, J.P., Kuslikis, B.I., Shrago, E., and Peterson, R.E. (1991). Inhibition of long-chain acyl-CoA synthetase by the peroxisome proliferator perfluorodecanoic acid in rat hepatocytes. Biochemical Pharmacology, 42, 295-302.

Vrolijk, N., Targett, M., Woodin, B.R., and Stegeman, J.J. (1994). Toxicological and ecological implications of biotransformation enzymes in the tropical teleost Chaetodon capistratus Marine Biology, 119, 151-158.

Zodrow, J.M., Stegeman, J.J., and Tanguay, R.L. (2004.) Histological analysis of acute toxicity of 2,3,7,8-tetrachlorodibenzo-p-dioxin (TCDD) in zebrafish. Aquatic Toxicology, 66, 25-38.

\section{ACKNOWLEDGMENTS}

This research was supported by the Environmental Toxicology Research Program of the University of Mississippi, and by the Australian Institute of Marine Science and Apache Energy Pty Ltd. We would like to thank the entire crew of the Lady Basten (pilot study) and the entire crew of the Cape Ferguson (caging study) for their assistance in the field. We would also like to thank Mary Johnston of the University of Maryland, Chesapeake Biological Laboratory for technical assistance on the Pilot Study samples, Cary McLean of AIMS for technical expertise during the caging study and Craig Skepper from WA Fisheries for all his assistance during the caging study. 
383

384

385

386

Table 1: Characteristics of Stripey seaperch used in the caged fish study. All of the fish were of intermediate reproductive status (sex-stage) and had plasma vitellogenin levels that were below the detection limit.

\begin{tabular}{|c|c|c|c|c|c|}
\hline $\begin{array}{c}\text { Holding Tank or } \\
\text { Cage Site }\end{array}$ & $\begin{array}{c}\text { Time } \\
(\text { days })\end{array}$ & $\begin{array}{c}\text { Sex Ratio } \\
\text { (Female/Male) }\end{array}$ & $\begin{array}{c}\text { Body Weight } \\
(\mathbf{g})\end{array}$ & $\begin{array}{c}\text { Body Length }^{*} \\
(\mathbf{m m})\end{array}$ & $\begin{array}{c}\text { Age }^{*} \\
(\mathbf{y r})\end{array}$ \\
\cline { 3 - 6 } Holding Tank & $\mathbf{0}$ & $(4 / 7)$ & $271 \pm 85$ & $261 \pm 22$ & $5 \pm 2$ \\
\hline & & & & & \\
& $\mathbf{3}$ & $(4 / 4)$ & $292 \pm 83$ & $265 \pm 30$ & $6 \pm 4$ \\
Reference Site C & $\mathbf{1 0}$ & $(4 / 4)$ & $284 \pm 52$ & $257 \pm 19$ & $4 \pm 2$ \\
\hline & & & & & \\
& $\mathbf{3}$ & $(0 / 5)$ & $273 \pm 123$ & $260 \pm 34$ & $5 \pm 3$ \\
Far-Field Site B & $\mathbf{1 0}$ & $(0 / 5)$ & $324 \pm 92$ & $269 \pm 21$ & $3 \pm 2$ \\
\hline & & & & & \\
& $\mathbf{3}$ & $(3 / 5)$ & $371 \pm 88$ & $285 \pm 20$ & $5 \pm 3$ \\
Near-Field Site A & $\mathbf{1 0}$ & $(1 / 4)$ & $293 \pm 79$ & $262 \pm 28$ & $5 \pm 2$ \\
\hline
\end{tabular}

$*$ Values are mean \pm SD for male and female combined. 


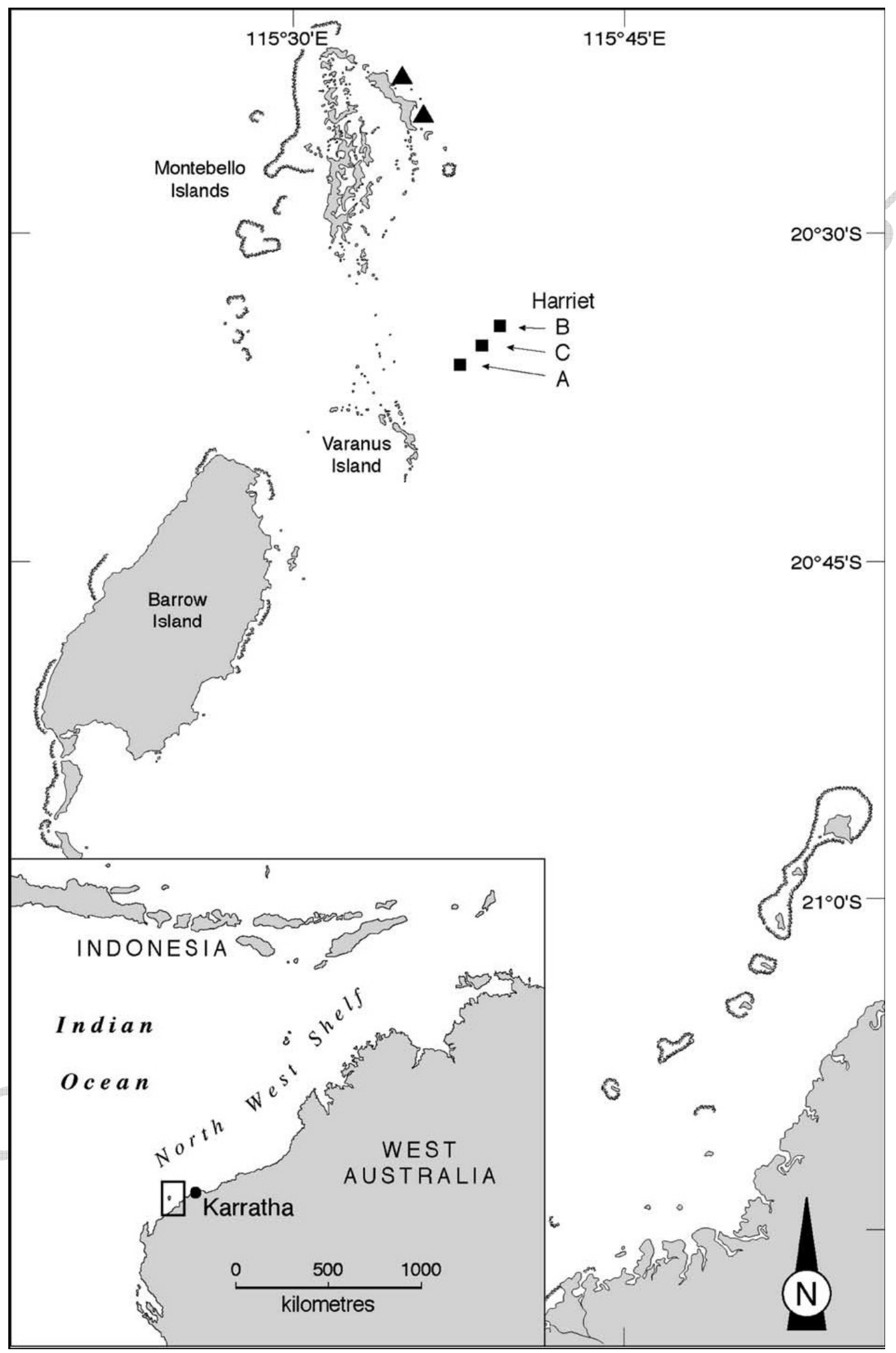

Figure 1: Pilot study site locations: Harriet A, Harriet B, Harriet C, and the reference sites, indicated by triangles, off the Montebello Islands. 


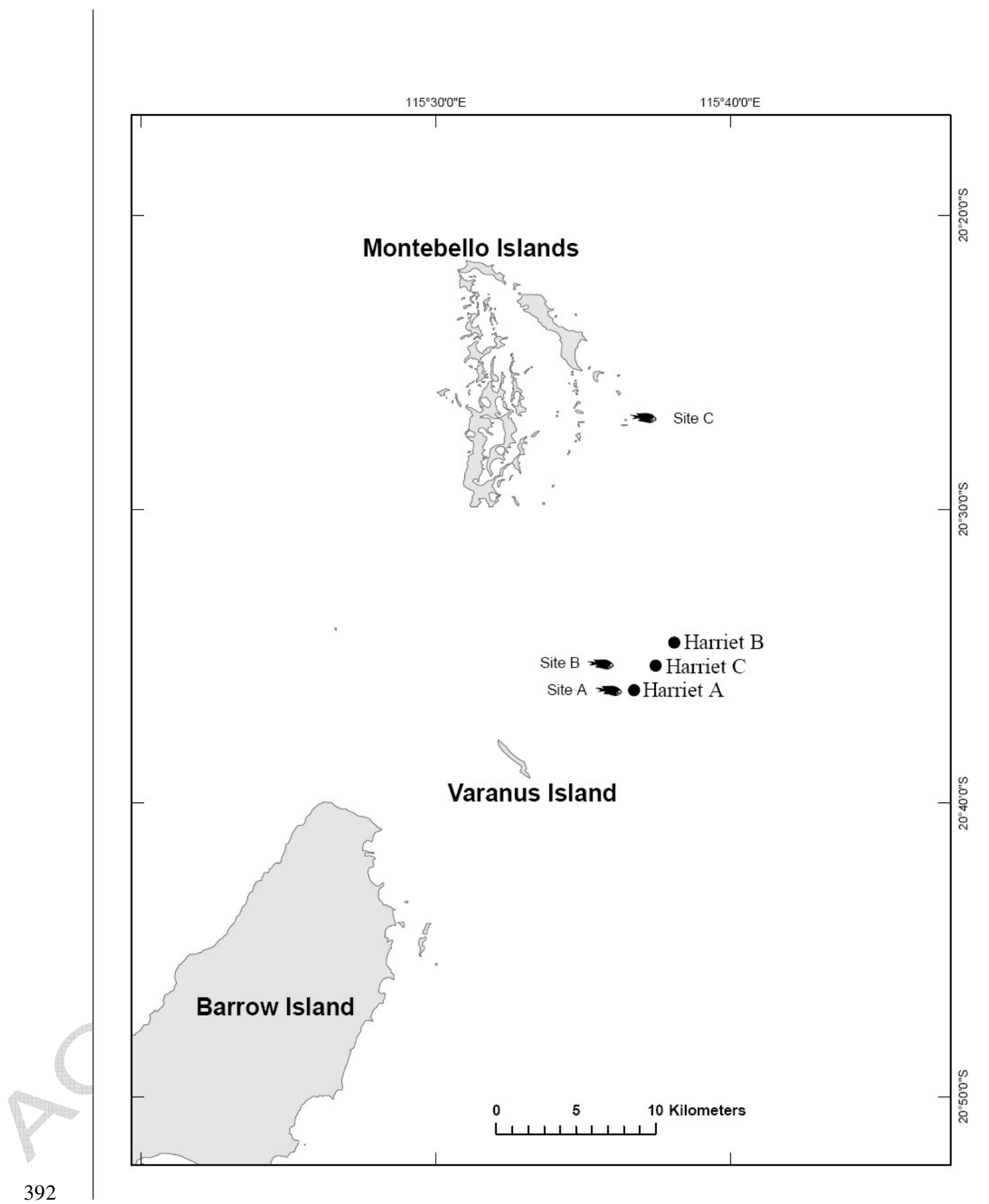

Figure 2. Site locations of the caged fish study: (Site A 200 m, Site B $\sim 1000 \mathrm{~m}$ and Site C $\sim 20 \mathrm{~km}$ ) 394 relative to the Harriet A PFW discharge. 


\section{ACCEPTED MANUSCRIPT}

396 Figure 3. Pilot study: the species specific pattern of CYP1A-, CYP2M1-, and CYP2K1- like proteins

397 determined in Gold-Spotted Trevally (shown for comparison of isozyme expression not for illustration 398 of site effects), and graphical representation of the optical densities (Mean \pm SD) determined for each

399 site. The molecular weight range of the proteins is typical of cytochromes P450 and is between 45 and $40060 \mathrm{kDa}$ for all three isozymes. Numbers above the bars indicate the number of female and male fish 401 (e.g., 6/2, female/male) represented in the average densitometry values. No statistical difference was 402 observed between genders.

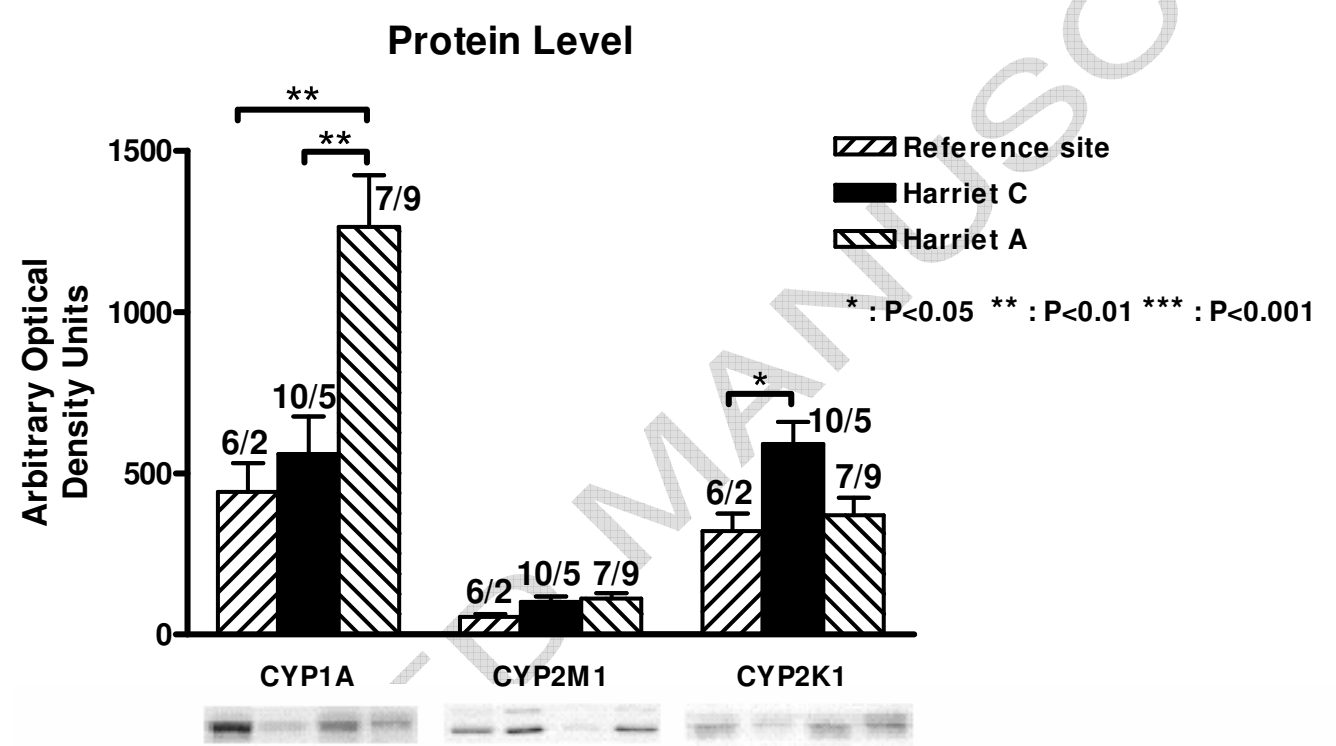


405 Figure 4 a-b. Caged fish study: the species-specific pattern of CYP1A-like proteins determined in

406 Stripey seaperch. (a) Image of the chemiluminescence detection of CYP1A-like proteins with a 407 single distinct band $(56.1 \mathrm{kDa})$ in the appropriate molecular weight range (shown for comparison 408 of isozyme expression not for illustration of site effects), and (b) graphical representation of the 409 optical densities (Mean \pm SD) determined in Stripey seaperch at each site over time. Numbers 410 above the bars indicate the number of female and male fish (e.g., $4 / 7$, female/male) represented in 411 the average densitometry values. No statistical difference was observed between genders.

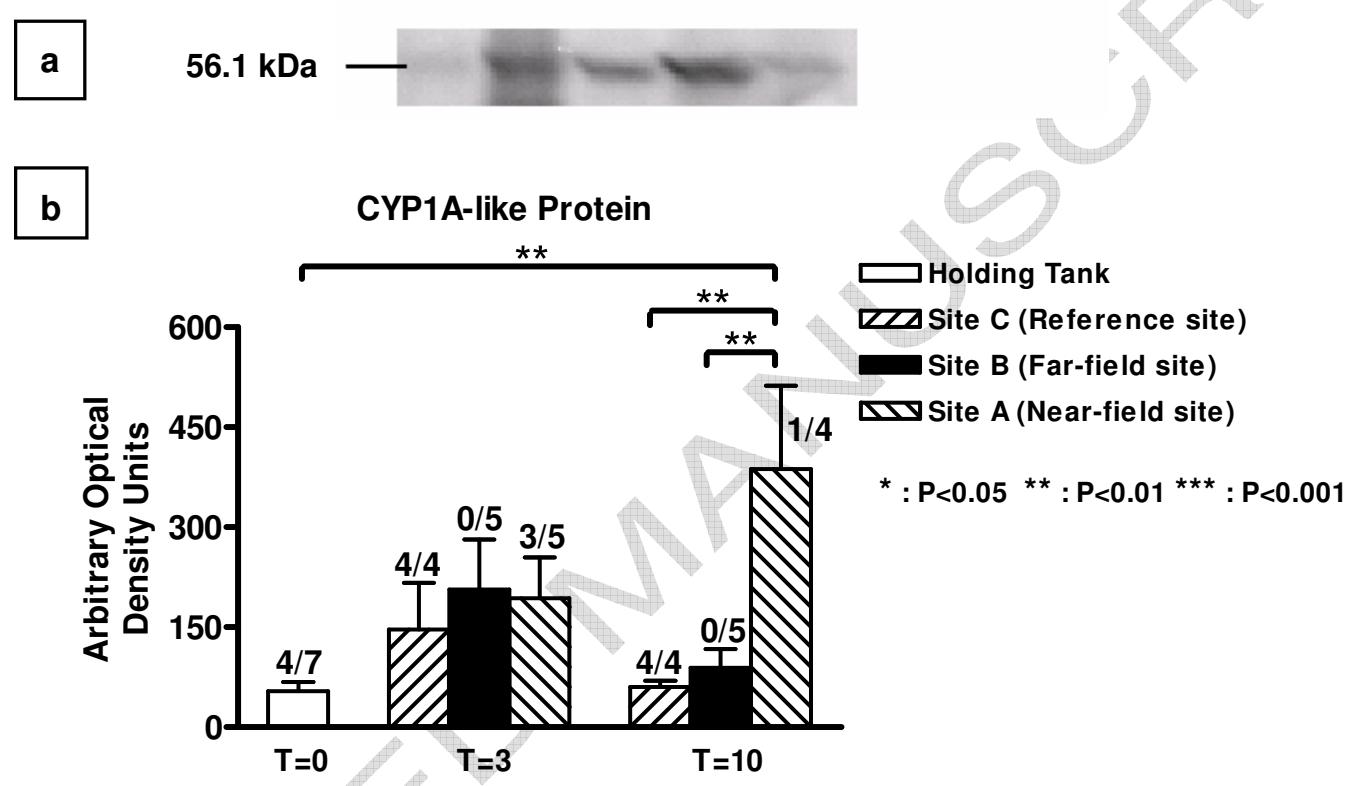


413 Figure 5 a-c. Caged fish study: the species specific pattern of CYP2M1-like proteins determined in

414 Stripey seaperch. (a) Image of the chemiluminescence detection of CYP2M1-like proteins with two 415 distinct bands of protein (shown for comparison of isozyme expression not for illustration of site 416 effects), (b) the graphical representation of optical densities (Mean \pm SD) determined for Protein 1 and 417 (c) for Protein 2. Numbers above the bars indicate the number of female and male fish (e.g., 4/7, 418 female/male) represented in the average densitometry values. No statistical difference was observed 419 between genders.

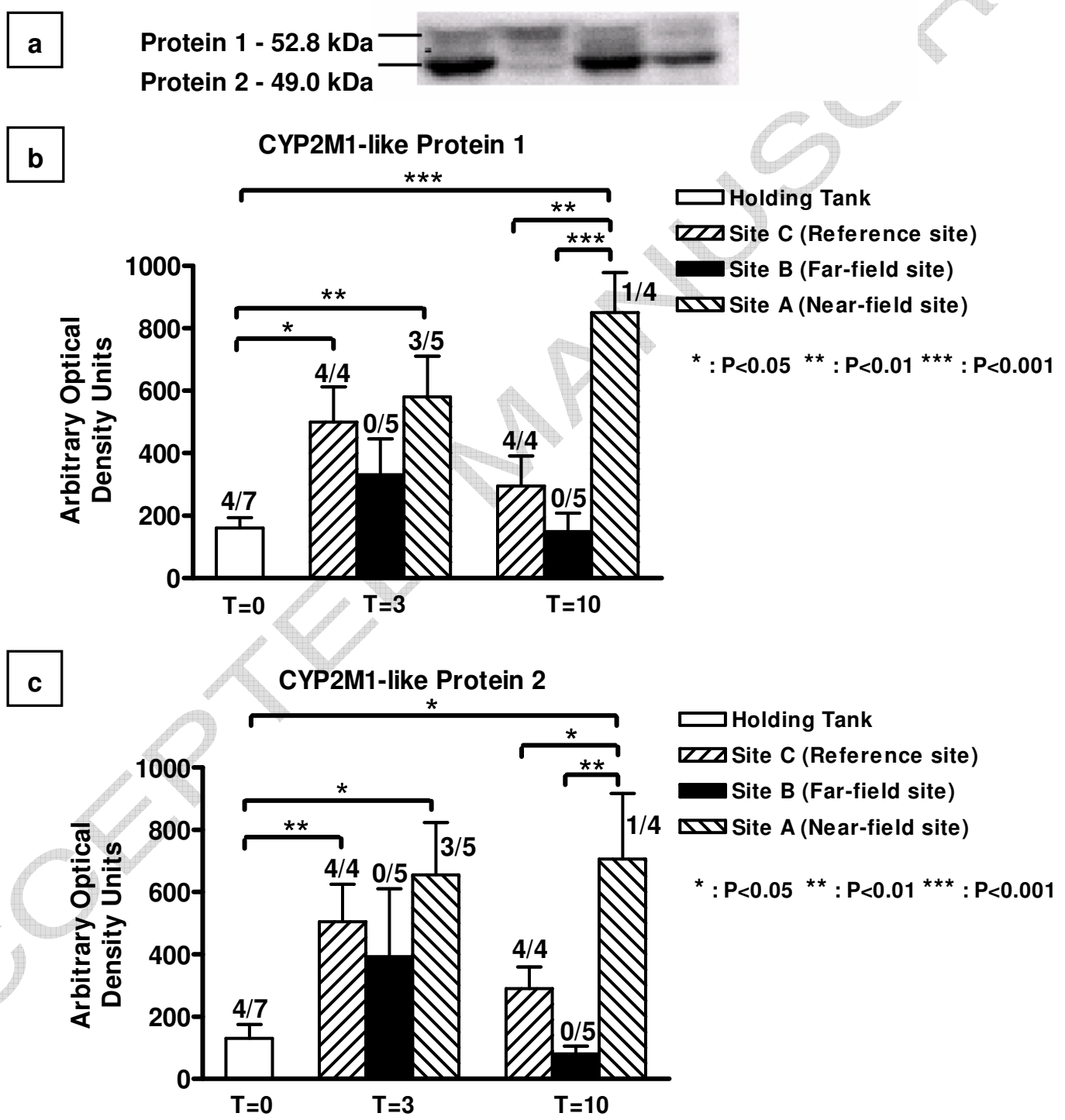


421 Figure 6 a-c. Caged fish study: the species specific pattern of CYP2K1-like proteins determined in

422 Stripey seaperch. (a) Image of the chemiluminescence detection of CYP2K1-like proteins with two 423 distinct bands of protein (shown for comparison of isozyme expression not for illustration of site 424 effects), (b) the graphical representation of optical densities (Mean \pm SD) determined for Protein 1 and (c) for Protein 2. Numbers above the bars indicate the number of female and male fish (e.g., 4/7, female/male) represented in the average densitometry values. No statistical difference was observed between genders.
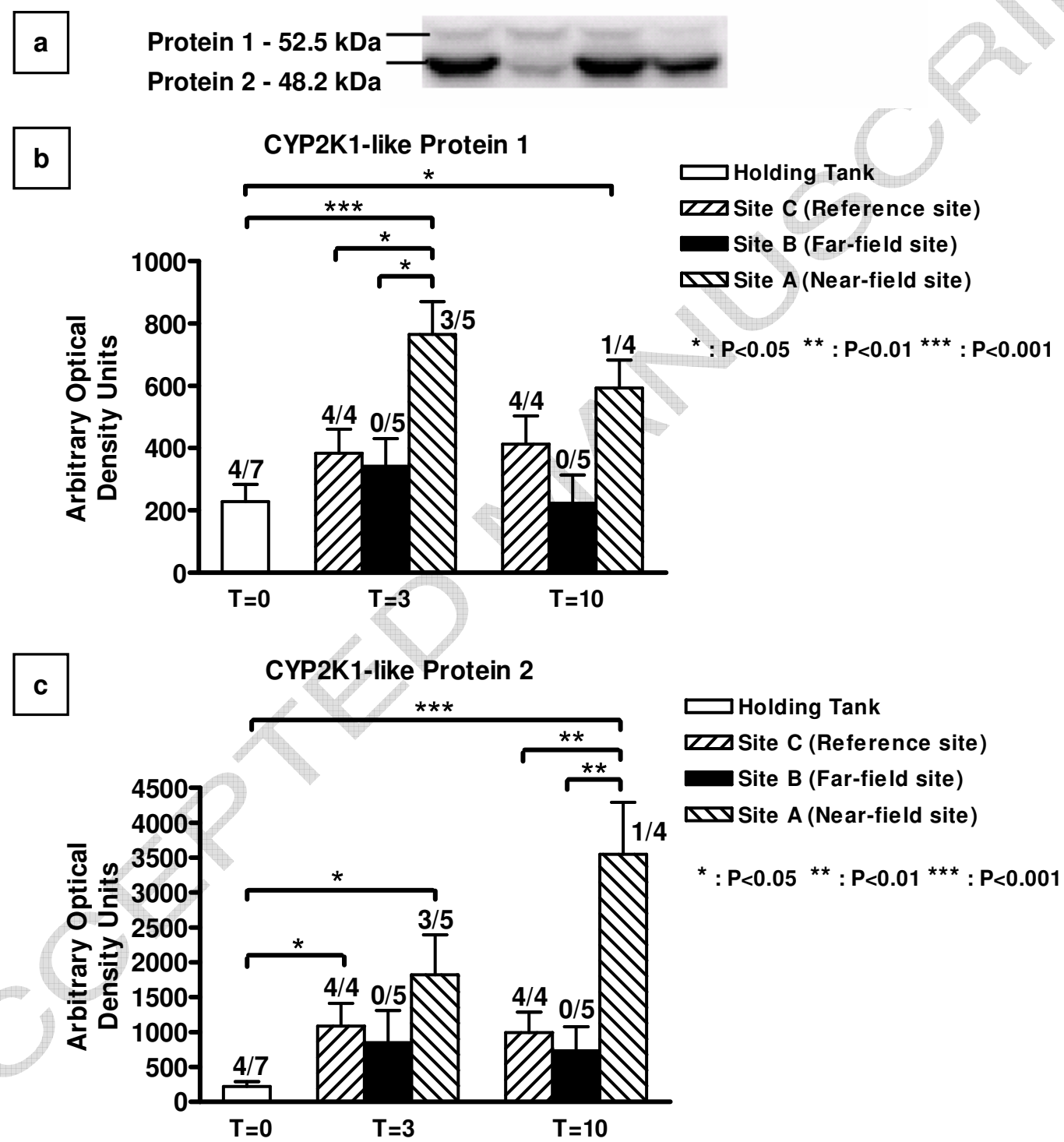